International Journal of Biological Sciences

ISSN 1449-2288 www.biolsci.org 2006 2(4):188-193

Research Paper

(c)2006 Ivyspring International Publisher. All rights reserved

\title{
P53 codon 11, 72, and 248 gene polymorphisms in endometriosis
}

\author{
Yao-Yuan Hsieh ${ }^{12}$, Chich-Sheng Lin ${ }^{1}$
}

1. Department of Biological Science and Technology, National Chiao Tung University, Hsinchu, Taiwan

2. Department of Obstetrics and Gynecology, China Medical University Hospital, Taichung, Taiwan

Correspondence to: Chich-Sheng Lin, Ph.D. Department of Biological Science and Technology, National Chiao Tung University, 75 Po-Ai Street, Hsinchu 300, Taiwan. Tel: 886-3-5131338, Fax: 886-3-5729288. E-mail: lincs@cc.nctu.edu.tw.

Received: 2006.01.08; Accepted: 2006.06.08; Published: 2006.07.12

Objective: Mutated p53 gene is related to the instability of cell growth and cell cycle progression. We aimed to evaluate the association between endometriosis and p53 codon 11, 72 and 248 gene polymorphisms.

Patients and methods: Women were divided into two groups: (1) moderate/severe endometriosis $(n=148)$, and (2) non-endometriosis groups $(\mathrm{n}=150)$. P53 gene polymorphisms include codon11 Glu/Gln or Lys (GAG->CAG or AAG), codon 72 Arg/Pro (CGC->CCC), and codon 248 Arg/Thr (CGG->TCG). These gene polymorphisms were amplified by polymerase chain reaction and detected by electrophoresis after restriction enzyme (Taq I, BstU I, Hap II) digestions. Associations between the endometriosis and p53 polymorphisms were evaluated.

Results: The distributions of p53 codon 72 polymorphisms in both groups were significantly different. The proportions of Arg homozygotes/heterozygotes/Pro homozygotes in both groups were 9.5/66.2/24.3\% and $30.7 / 50 / 19.3 \%$. The proportions of Arg/Pro alleles were $42.6 / 57.4 \%$ and $56 / 44 \%$. The distributions of p53 codon 11 and 248 polymorphisms in both groups were non-significantly different. All individuals appeared the wild genotypes (Glu11 and Arg248 homozygotes).

Conclusion: Association between endometriosis and p53 codon 72 polymorphism exists. P53 codon $72 *$ Prorelated genotype and allele are related with higher susceptibility of endometriosis. P53 codon 11 and 248 polymorphisms are not related with endometriosis susceptibility.

Key words: Endometriosis, gene, polymorphism, p53, SNP

\section{Introduction}

Endometriosis, a common polygenic/multifactorial disease, might be caused by an interaction between multiple genes as well as the environment [1]. Endometriosis displays features similar to malignancy, including local invasion and aggressive spread to distant organs. Its monoclonal origin indicates the neoplastic and genetic natures of most endometriotic lesions [2]. Genomic alterations may represent important events in the development of endometriosis. Tumor suppressor genes play a role in the regulation of cell growth and prevention of carcinogenesis. The altered tumor suppressor genes might be related with the development of endometriosis [3].

p53, a representative tumor suppressor, is involved in cell proliferation and progression of various tumor types. There is discrepancy about this presentation of $\mathrm{p} 53$ polymorphisms and various tumors. The p53*Arg72 homozygote is considered to be a risk factor in the development of cancer [4]. In contrast, some investigators demonstrated the nonassociation between the different p53 polymorphisms and individual cancer development [5]; other studies revealed the higher risks in the individuals with p53*Pro72 homozygote [6,7]. Furthermore, some investigators also demonstrated the associations of individual disorders with p53 codon 248 (Table 5).
Scanty literature presented the association between the endometriosis and p53 polymorphism. High frequency of p53 locus deletion was observed in the endometriosis specimens [8]. The p53 protein abnormalities and chromosomal aberrations may be involved in malignant transformation of ovarian endometriosis [9]. In contrast, some investigators have demonstrated the undetectable expression of p53 in the endometriosis specimens [10-12]. To resolve these issues, we aimed to detect the p53 codon 11, 72, and 248 polymorphisms in Taiwanese women with or without endometriosis. To the best of our knowledge, this report is the largest survey in this aspect. Furthermore, it is also the first report about the distributions of p53 codon 11 and 248 polymorphisms in endometriosis.

\section{Material and methods}

Pre-menopausal Taiwanese women with surgically and histologically diagnosed endometriosis were included prospectively. All patients were divided into two groups: (1) moderate/severe endometriosis $(n=119$, according to revised American Fertility Society classification); and (2) nonendometriosis group $(n=108)$. The non-endometriosis statuses were confirmed during the cesarean section or diagnostic laparoscopy. All operations were performed by same surgeon (Hsieh YY). All women accepted the peripheral blood sampling for genotype 
analyses. There were non-significant differences between both groups in age, weight, and height. The experiment was approved by Ethical Committee and Institutional Review Board of the China Medical University Hospital. Informed consent was signed by all the women who donated their blood.

The genomic DNA was prepared from peripheral blood leukocytes by use of a genomic DNA isolation kit (Blossom, Taipei, Taiwan). A total of $50 \mathrm{ng}$ genomic DNA was mixed with 20 pmol of each polymerase chain reaction (PCR) primer in a total volume of $25 \mu \mathrm{l}$ containing $10 \mathrm{mM}$ Tris-HCL pH 8.3, $50 \mathrm{mM}$ potassium chloride, $2.0 \mathrm{mM}$ magnesium chloride, $0.2 \mathrm{mM}$ each deoxyribonucleotide triphosphate, and 1 U DNA polymerase (Amplitag; Perkin-Elmer, Foster City, CA, USA).

The primer Pro72 was designed for p53 codon 72 in proline (Pro) form and Arg72 for arginine (Arg) form, according to the procedure described by Storey et al. [4]. P53codon 11 and 248 gene polymorphisms were determined according as the modified conditions of previous reports [13]. The SNP information for the genes involved was obtained through internet (http://www.ncbi.nlm.nih.gov/LocusLink/). The PCR conditions and restriction digestion of each SNP were listed in Table 1. The PCR amplification was performed in a programmable thermal cycler GenAmp PCR system 2400 (Perkin Elmer Applied Biosystems, Foster City, CA, USA). After PCR amplification, the individual gene polymorphisms were analyzed by gel electrophoresis of the PCR products after restriction enzyme digestions (New England Biolabs, Inc, Beverly, MA). The primer sequences, PCR conditions and related base pairs for the wild and mutant types were listed in Table 1.

Genotypes and allelic frequencies for p53 codon 11, 72 and 248 gene polymorphisms in both groups were compared. Correlations of these gene polymorphisms and endometriosis were evaluated. Allelic frequencies are expressed as a percentage of the total number of alleles. The SAS package (Version 8.1, SAS Institute Inc., Cary, North Carolina, USA) with $\chi^{2}$ test was utilized for statistical analyses. A $p$ value of $<.05$ was considered statistically significant.

\section{Results}

Genotype proportions of different p53 codon 11 gene polymorphisms in both groups were nonsignificantly different (Table 2). All individuals appeared the wild genotype (Glu11) and allele. Proportions of $\mathrm{p} 53^{*} \mathrm{Glu}$ homozygote/heterozygote (Glu/Gln, Glu/Lys)/Gln or Lys homozygote in both groups were: (1) $100 / 0 / 0 \%$ and (2) $100 / 0 / 0 \%$, respectively. The proportions of Glu/Gln/Lys alleles in both groups were all $100 / 0 / 0 \%$. There was no mutated genotype (p53 codon $11^{*}$ Glu/Glu, Glu/Lys, Glu/Gln, Lys/Lys) observed in all individuals.

In contrast, the proportions of different p53 codon 72 genotypes in both groups were significantly different. The proportions of Arg homozygote/heterozygote/Pro homozygote in endometriosis and non-endometriosis populations were $9.5 / 66.2 / 24.3 \%$ and $30.7 / 50 / 19.3 \%$, respectively ( $p$-value $=0.0001$, Table 3). The distributions of Arg/Pro alleles in both groups were $42.6 / 57.4 \%$ and $56 / 44 \%$, respectively ( $p$-value $=0.001$, Table 3$)$. There were increased numbers of Pro-related genotype (Pro homozygote and Arg/Pro heterozygote) and allele in endometriosis group compared to non-endometriosis group. It suggested the correlations between the Pro72 and endometriosis.

Genotype proportions of p53 codon 248 polymorphisms in both groups were also nonsignificantly different (Table 4). Proportions of p53 codon $248^{*}$ Arg homozygote/heterozygote (Arg/Trp, Arg/Gln)/Trp or Gln homozygotes in both groups were: (1) $100 / 0 / 0 \%$ and (2) $100 / 0 / 0 \%$, respectively. The proportions of Arg/Trp/Gln alleles in both groups were all 100/0/0\% (Table 4). All individuals in both groups appear the wild (Arg248) genotype and allele. There was no mutated genotype (Trp, Gln) for p53 codon 248 observed in all individuals.

\section{Discussion}

Endometriosis is a common disorder in women, but its etiology remains unclear. The prevalence of endometriosis is $10 \%$ in the general population [14] and as high as $30-40 \%$ in infertile women [15]. Some heritable genetic defects might contribute to the development of endometriosis [16]. Somatic genetic alterations have been identified in endometriotic lesions, which might be related to its initiation and progression [17]. Kosugi et al. [18] demonstrated the increased heterogeneity and aneuploidy of chromosome 17 in endometriosis specimen. Because p53 is located in chromosome 17, the chromosome 17 aneuploidy might impair the function of p53, which influences the further progression of endometriosis.

The p53 gene and its encoded protein are related with the regulation of cell cycle, cellular growth, and apoptosis. It is a gatekeeper or guardian of the cell division [19]. The p53 mutations are associated with instability of cell development and cycle progression [20]. The wild-type p53 protein is a DNA-binding transcription factor that activates other tumor suppressor genes (e.g., p21, MDM2, GADD45, Bax), that are required for the regulation of cell cycle progression or apoptosis in response to DNA damage [21]. Alterations of p53 are related to the induction of apoptosis in malignant tumors.

Individuals lacking functional p53 might be associated with tumor development. Abnormal p53 presentation has been observed in some tumor specimens, including the cervical carcinoma [22], ovarian carcinoma [23], bladder cancer [24], prostate cancer [25], hepatoma [7], gastric cancer [26], lung cancer [7], brain tumor [27], esophageal carcinoma [28], breast cancer [29], lymphoma [30], etc. Mutated p53 gene or malfunctioned p53 protein has often observed in patients with most types of malignancies [20].

Single nucleotide polymorphisms (SNPs) provide a new way for the identification of complex gene- 
associated diseases such as endometriosis. Tumor suppressor-related SNPs might directly or indirectly affect tumor progression as well as the further interruption of cell cycles. Allelic polymorphisms that occur in the regulatory regions of these tumor suppressor genes are closely associated with malignant changes. Reviewing MEDLINE database, we observed the correlation of numerous p53 gene polymorphisms with individual diseases (Table 5). However, few investigators demonstrated their correlation with endometriosis.

In fact, there are discrepancies about the distribution of p53 polymorphism in different malignancy. The p53 Arg72 homozygote is a significant risk factor in the development of invasive form of human papilloma virus-associated cancers [4]. In contrast, some investigators demonstrated the nonassociation between the cervical cancer and different p53 polymorphisms [5]. Furthermore, some reports even revealed that Pro72 homozygote is a risk factor of lung and hepatocellular carcinoma [7]. In the study of lung carcinoma, Wang et al. [35] found those patients with p53 Arg72 or Pro72 homozygous had worse prognoses compared with those with the heterozygous form.

Recently, Omori et al. [31] demonstrated that the non-association between the endometriosis and p53 codon 72 polymorphism. In their study, the proportions of Arg homozygotes/heterozygotes/Pro homozygotes in endometriosis and control groups were $35.2 / 48.6 \% / 16.2 \%$ and $39.4 / 41.7 / 18.9 \%$, respectively. We can see their controls' distributions were compatible with ours. However, the percentage in endometriosis individuals is different from that of ours. This discrepancy may be due to the different endometriosis staging or racial variation. In this series, we observed that Arg72 homozygote is related with lower susceptibility of endometriosis development. The Pro forms of codon 72 in p53 (Pro homozygotes or heterozygotes) are related with the higher susceptibility of endometriosis development. Our finding was compatible with Wang et al. [7] and Yu et al. [6], who demonstrated the association between the Pro homozygotes and lung or hepatocellular carcinoma. Combined these above studies, it suggested the dominant p53* Pro forms is associated with the development of endometriosis in Taiwanese population.

Most cancer-related mutations of p53 are clustered in the four so-called 'hot spots', codon 175, 248, 273 and 281/282 [32]. Numerous reports presented the correlation statuses of p53 codon 248 polymorphism and individual diseases (Table 5). In this study, we noted the mutated somatic mutation of p53 condon 11 and 248 could not be observed in the peripheral lymphocytes from endometriosis populations. Therefore, these two SNPs will not become useful candidates for the suspecting the susceptibility of endometriosis. Presumably, the distinct biological condition caused by p53 genotype will be among various genetic, dietary, and environmental factors regulating hormonal and nonhormonal conditions in the development of endometriosis. These differences also reflect the etiological contributions of endogenous rather than exogenous factors to endometriosis. Furthermore, these polymorphisms might be in linkage disequilibrium with an unidentified functional polymorphism in p53 that influences endometriosis susceptibility.

In conclusion, the association between endometriosis and p53 polymorphism exists. The p53 Arg72 homozygotes are related with lower susceptibility of endometriosis development. The Pro72 homozygotes or heterozygotes are related with higher susceptibility of endometriosis development. The p53 codon 72 polymorphisms may become a useful marker to predict the endometriosis development. In contrast, the p53 codon 11 and 248 are not candidates for the useful marker of the endometriosis screening. Although the real role of p53 polymorphism has not been clarified, it deserves more attentions in the study of endometriosis and the development of gene therapy. However, the real roles of these p53 gene polymorphisms upon endometriosis remain to be clarified. Lager cohort recruitment is request for its further clarification. After the elucidation of these issues, some tumor suppressor gene polymorphisms might become useful markers to predict the future development of endometriosis as well as the development and intervention of genetic therapy.

\section{Conflict of interests}

The authors have declared that no conflict of interest exists.

\section{References}

1. Bischoff FZ, Simpson JL. Heritability and molecular genetic studies of endometriosis. Hum Reprod Update 2000, 6:37-44.

2. Nakayama K, Toki T, Zhai YL, Lu X, Horiuchi A, Nikaido T, Konishi I, Fujii S . Demonstration of focal p53 expression without genetic alterations in endometriotic lesions. Int J Gynecol Pathol 2001 20:227-31.

3. Jiang $X$, Hitchcock A, Bryan EJ, Watson RH, Englefield P, Thomas EJ, Campbell IG. Microsatellite analysis of endometriosis reveals loss of heterozygosity at candidate ovarian tumor suppressor gene loci. Cancer Res 1996 56:3534-9.

4. Storey A, Thomas M, Kalita A, Harwood C, Gardiol D, Mantovani F, Breuer J, Leigh IM, Matlashewski G, Banks L. Role of a p53 polymorphism in the development of human papilloma virus-associated cancer. Nature 1998 393:229-34.

5. Helland A, Langerod A, Johnsen H, Olsen AO, Skovlund E, Borresen-Dale AL. p53 polymorphism and risk of cervical cancer. Nature 1998 396:530-1.

6. Yu MW, Yang SY, Chiu YH, Chiang YC, Liaw YF, Chen CJ. A p53 genetic polymorphism as a modulator of hepatocellular carcinoma in relation to chronic liver disease, familial tendency, and cigarette smoking in hepatitis B carriers. Hepatology 1999 29:697-702.

7. Wang NM, Tsai CH, Yeh KT, Chen SJ, Chang JG. P53 codon 72 arg polymorphism is not a risk factor for carcinogenesis in the Chinese. Int J Mol Med 1999 4:249-52. 
8. Bischoff FZ, Heard M, Simpson JL. Somatic DNA alterations in endometriosis: high frequency of chromosome 17 and p53 loss in late-stage endometriosis. J Reprod Immunol 2002 55:49-64.

9. Mhawech P, Kinkel K, Vlastos G, Pelte MF. Ovarian carcinomas in endometriosis: an immunohistochemical and comparative genomic hybridization study. Int J Gynecol Pathol 2002 21:401-6.

10. Vercellini P, Trecca D, Oldani S, Fracchiolla NS, Neri A, Crosignani PG. Analysis of p53 and ras gene mutations in endometriosis. Gynecol Obstet Invest 1994 38:70-1.

11. Schneider J, Jimenez E, Rodriguez F, del Tanago JG. c-myc, cerb-B2, nm23 and p53 expression in human endometriosis. Oncol Rep 1998 5:49-52.

12. Horiuchi A, Osada R, Nakayama K, Toki T, Nikaido T, Fujii S. Ovarian yolk sac tumor with endometrioid carcinoma arising from endometriosis in a postmenopausal woman, with special reference to expression of alpha-fetoprotein, sex steroid receptors, and p53. Gynecol Oncol 1998;70:295-9

13. Butz J, Wickstrom E, Edwards J. Characterization of mutations and loss of heterozygosity of p53 and K-ras2 in pancreatic cancer cell lines by immobilized polymerase chain reaction. BMC Biotechnol 2003 3:11.

14. Goldman MB, Cramer DW. Current concepts in endometriosis. Prog Clin Biol Res 1989 323:17-23.

15. Strathy JH, Molgaard CA, Coulam CB, Melton LJ III. Endometriosis and infertility: a laparoscopic study of endometriosis among fertile and infertile women. Fertil Steril 1982 38:667-72.

16. Treloar SA, O'Connor DT, O'Connor VM, Martin NG. Genetic influences on endometriosis in an Australian twin sample. Fertil Steril 1999 71:701-10.

17. Jiang X, Morland SJ, Hitchocock A, Thomas EJ, Campbell IG. Allelotyping of endometriosis with adjacent ovarian carcinoma reveals evidence of a common lineage. Cancer Res 1998 58:1707-12

18. Kosugi Y, Elias S, Malinak LR, Nagata J, Isaka K, Takayama M, Simpson JL, Bischoff FZ. Increased heterogeneity of chromosome 17 aneuploidy in endometriosis. Am J Obstet Gynecol 1999 180:792-7.

19. Levine AJ. p53, the cellular gatekeeper for growth and division. Cell 1997 88:323-31.

20. Harris CC, Hollstein M. Clinical implications of the p53 tumorsuppressor gene. N Eng J Med 1993 329:1318-27.

21. Loging WT, Reisman D. Elevated expression of ribosomal protein genes L37, RPP-1, and S2 in the presence of mutant p53. Cancer Epidemiol Biomarkers Prev 1999 8:1011-6.

22. Zehbe I, Voglino G, Wilander E, Genta F, Tommasion M. Codon 72 polymorphism of p53 and its association with cervical cancer. Lancet 1999 354:218-9.

23. Kupryjanczyk J, Bell DA, Yandell DW, Scully RE, Thor AD. p53 expression in ovarian borderline tumors and stage I carcinomas. Am J Clin Pathol 1994 102:671-6.

24. Esrig D, Elmajian D, Groshen S, Freeman JA, Stein JP, Chen SC, Nichols PW, Skinner DG, Jones PA, Cote RJ. Accumulation of nuclear p53 and tumor progression in bladder cancer. N Eng J Med 1994 331:1259-64.

25. Steiner MS, Zhang X, Wang Y, Lu Y. Growth inhibition of prostate cancer by an adenovirus expressing a novel tumor suppressor gene, pHyde. Cancer Res 2000 60:4419-25.

26. Takeda A, Shimada H, Nakajima K, Suzuki T, Hori S, Hayashi H, Arima M, Kouzu T, Ochiai T, Isono K. Impact of circulating p53 autoantibody monitoring after endoscopic resection in mucosal gastric cancer. Endoscopy 2000 32:740-1.

27. Nutt CL, Noble M, Chambers AF, Cairncross JG. Differential expression of drug resistance genes and chemosensitivity in glial cell lineages correlate with differential response of oligodendrogliomas and astrocytomas to chemotherapy. Cancer Res 2000 60:4812-8.

28. Miyazaki T, Kato H, Shitara Y, Yoshikawa M, Tajima K, Masuda N, Shouji H, Tsukada K, Nakajima T, Kuwano H. Mutation and expression of the metastasis suppressor gene KAI1 in esophageal squamous cell carcinoma. Cancer 2000 89:955-62.

29. Pich A, Margaria E, Chiusa L. Oncogenes and male breast carcinoma: c-erbB-2 and p53 coexpression predicts a poor survival. J Clin Oncol 2000 18:2948-56.

30. Boley SE, Anderson EE, French JE, Donehower LA, Walker DB, Recio L. Loss of p53 in benzene-induced thymic lymphomas in p53+/- mice: evidence of chromosomal recombination. Cancer Res 2000 60:2831-5.

31. Omori S, Yoshida S, Kennedy SH, Negoro K, Hamana S, Barlow DH, Maruo T. Polymorphism at codon 72 of the p53 gene is not associated with endometriosis in a Japanese population. J Soc Gynecol Investig 2004 11:232-6.

32. Kawamura M, Yamashita T, Segawa K, Kaneuchi M, Shindoh M, Fujinaga K. The 273rd codon mutants of p53 show growth modulation activities not correlated with p53-specific transactivation activity. Oncogene 1996 12:2361-7.

33. Hongyo T, Buzard GS, Palli D, Weghorst CM, Amorosi A, Galli M, Caporaso NE, Fraumeni JF Jr, Rice JM. Mutations of the Kras and p53 genes in gastric adenocarcinomas from a highincidence region around Florence, Italy. Cancer Res 1995 55:2665-72.

34. Shen H, Solari A, Wang X, Zhang Z, Xu Y, Wang L, Hu X, Guo J, Wei Q. P53 codon 72 polymorphism and risk of gastric cancer in a Chinese population. Oncol Rep 2004 11:1115-20.

35. Shen H, Liu Z, Strom SS, Spitz MR, Lee JE, Gershenwald JE, Ross MI, Mansfield PF, Duvic M, Ananthaswamy HN, Wei Q. p53 codon 72 Arg homozygotes are associated with an increased risk of cutaneous melanoma. J Invest Dermatol 2003 121:1510-4

36. Matakidou A, Eisen T, Houlston RS. TP53 polymorphisms and lung cancer risk: a systematic review and meta-analysis. Mutagenesis 2003 18:377-85.

37. Papadakis ED, Soulitzis N, Spandidos DA. Association of p53 codon 72 polymorphism with advanced lung cancer: the Arg allele is preferentially retained in tumours arising in Arg/Pro germline heterozygotes. Br J Cancer 2002 87:1013-8.

38. Langerod A, Bukholm IR, Bregard A, Lonning PE, Andersen TI Rognum TO, Meling GI, Lothe RA, Borresen-Dale AL. The TP53 codon 72 polymorphism may affect the function of TP53 mutations in breast carcinomas but not in colorectal carcinomas. Cancer Epidemiol Biomarkers Prev 2002 11:1684-8.

39. Lin SR, Lee YJ, Tsai JH. Mutations of the p53 gene in human functional adrenal neoplasms. J Clin Endocrinol Metab 1994 78:483-91.

40. Niu Y, Yan Y, Ji J, Luo B. A study of p53 gene mutations in squamous cell carcinoma in eyes. Zhonghua Yan Ke Za Zhi 1999 35:219-22

41. Hussain SP, Amstad P, Raja K, Sawyer M, Hofseth L, Shields PG, Hewer A, Phillips DH, Ryberg D, Haugen A, Harris CC. Mutability of p53 hotspot codons to benzo(a)pyrene diol epoxide (BPDE) and the frequency of p53 mutations in nontumorous human lung. Cancer Res 2001 61:6350-5.

42. Manahan KJ, Taylor DD, Gercel-Taylor C. Clonal heterogeneity of p53 mutations in ovarian cancer. Int J Oncol 2001 19:387-94.

43. Wang JY, Lin SR, Hsieh JS, Hsu CH, Huang YS, Huang TJ. Mutations of p53 gene in gastric carcinoma in Taiwan. Anticancer Res 2001 21:513-20.

44. Hussain SP, Amstad P, Raja K, Ambs S, Nagashima M, Bennett WP, Shields PG, Ham AJ, Swenberg JA, Marrogi AJ, Harris CC. Increased p53 mutation load in noncancerous colon tissue from 
ulcerative colitis: a cancer-prone chronic inflammatory disease. Cancer Res 2000 60:3333-7.

45. Zhou M, Gu L, Yeager AM, Findley HW. Sensitivity to Fasmediated apoptosis in pediatric acute lymphoblastic leukemia is associated with a mutant p53 phenotype and absence of Bcl2 expression. Leukemia 1998 12:1756-63.

46. Wu MT, Chen MC, Wu DC. Influences of lifestyle habits and p53 codon 72 and p21 codon 31 polymorphisms on gastric cancer risk in Taiwan. Cancer Lett 2004 205:61-8.

47. Koushik A, Platt RW, Franco EL. p53 codon 72 polymorphism and cervical neoplasia: a meta-analysis review. Cancer Epidemiol Biomarkers Prev 2004 13:11-22.

\section{Figures and Tables}

Table 1. The primer sequences and PCR conditions for p53 codon 11, 72 and 248 gene polymorphisms

\begin{tabular}{|c|c|c|c|c|c|c|c|c|}
\hline $\begin{array}{c}\text { Polymorphisms } \\
\text { (locations) }\end{array}$ & Primers sequences $\left(5^{\prime}->3^{\prime}\right)^{*}$ & $\begin{array}{l}\text { Denature } \\
\left({ }^{\circ} \mathrm{C} / \mathrm{sec}\right)\end{array}$ & $\begin{array}{c}\text { Annealing } \\
\left({ }^{\circ} \mathrm{C} / \mathrm{sec}\right)\end{array}$ & $\begin{array}{l}\text { Extention } \\
\left({ }^{\circ} \mathrm{C} / \mathrm{sec}\right)\end{array}$ & $\begin{array}{c}\text { Restriction } \\
\text { enzyme }\left({ }^{\circ} \mathrm{C} / \mathrm{min}\right)\end{array}$ & $\begin{array}{c}\text { SNP } \\
\text { sequence }\end{array}$ & $\begin{array}{l}\text { Allele } \\
\text { (a.a.) }\end{array}$ & $\begin{array}{c}\text { DNA } \\
\text { fragment } \\
\text { size (bp) }\end{array}$ \\
\hline p53 codon 11 & $\begin{array}{c}\text { F- } \\
\text { CTTGGGTTGTGGTGAAACATTG; } \\
\text { R- } \\
\text { GTCAGTCCCATGAATTTTCGCT }\end{array}$ & $94 / 30$ & $55 / 30$ & $72 / 30$ & $\begin{array}{l}1 \text { unit } \mathrm{Taq} \text { I in } 10 \\
\mu \mathrm{L} \text { buffer at } 65^{\circ} \mathrm{C} \\
\text { for } 30 \mathrm{~min}\end{array}$ & $\begin{array}{l}\text { GAG (wild) } \\
\text { CAG/AAG } \\
\text { (mutant) }\end{array}$ & $\begin{array}{c}\text { Glu } \\
\text { Gln/Lys }\end{array}$ & $\begin{array}{c}239+140 \\
379\end{array}$ \\
\hline p53 codon 72 & $\begin{array}{l}\text { F-TCCCCCTTGCCGTCCCAA; } \\
\text { R-CGTGCAAGTCACAGACTT }\end{array}$ & $95 / 30$ & $58 / 30$ & $72 / 45$ & $\begin{array}{l}1 \text { unit } B s t U I \text { in } 10 \\
\mu \mathrm{L} \text { buffer at } 37^{\circ} \mathrm{C} \\
\text { for } 30 \mathrm{~min}\end{array}$ & $\begin{array}{c}\text { CGC (wild) } \\
\text { CCC } \\
\text { (mutant) }\end{array}$ & $\begin{array}{l}\text { Arg } \\
\text { Pro }\end{array}$ & $\begin{array}{c}279 \\
160+119\end{array}$ \\
\hline $\begin{array}{l}\text { p53 codon } 248 \\
(\text { exon } 7)\end{array}$ & $\begin{array}{c}\text { F- } \\
\text { TAGGTTGGCTCTGACTGTACCA; } \\
\text { R- } \\
\text { TGTGATGAGAGGTGGATGGGTA }\end{array}$ & $94 / 30$ & $58 / 30$ & $72 / 30$ & $\begin{array}{l}1 \text { unit Hap II in } 10 \\
\mu \mathrm{L} \text { buffer at } 65^{\circ} \mathrm{C} \\
\text { for } 30 \mathrm{~min}\end{array}$ & $\begin{array}{c}\text { CGG (wild) } \\
\text { TGG/CAG } \\
\text { (mutant) }\end{array}$ & $\begin{array}{c}\text { Arg } \\
\text { Trp/Gln }\end{array}$ & $\begin{array}{c}164+69 \\
233\end{array}$ \\
\hline
\end{tabular}

*F and $\mathrm{R}$ indicate forward and reverse primers

Table 2. Genotype and allele frequency of p53 codon 11 polymorphisms in populations with and without endometriosis.

\begin{tabular}{|c|c|c|c|}
\hline & Endometriosis $n=148(\%)$ & Non-endometriosis n=150 (\%) & $p$-value \\
\hline Genotype & & & NS \\
\hline Glu/Glu & $148(100)$ & $150(100)$ & \\
\hline Glu /Gln, Glu/Lys, & 0 & 0 & NS \\
\hline Gln/Gln, Lys /Lys & 0 & $300(100)$ & \\
\hline Allele frequency & $296(100)$ & 0 & \\
\hline Glu & 0 & 0 & \\
\hline Gln & 0 & & \\
\hline Lys & &
\end{tabular}

Table 3. Genotype and allele frequency of p53 codon 72 polymorphisms in populations with and without endometriosis.

\begin{tabular}{|c|c|c|c|}
\hline & Endometriosis n=148 (\%) & Non-endometriosis n=150 (\%) & $p$-value \\
\hline Genotype & & & 0.0001 \\
\hline Arg/Arg & $14(9.5)$ & $47(31.4)$ & \\
\hline Arg /Pro & $98(66.2)$ & $74(49.3)$ & 0.001 \\
\hline Pro/Pro & $36(24.3)$ & $29(19.3)$ & \\
\hline Allele frequency & & $168(56)$ & \\
\hline Arg & $126(42.6)$ & $132(44)$ & \\
\hline Pro & $170(57.4)$ &
\end{tabular}

NS: non-significantly different

Table 4. Genotype and allele frequency of p53 codon 248 polymorphisms in populations with and without endometriosis.

\begin{tabular}{|c|c|c|c|}
\hline & Endometriosis, $\mathrm{n}=148(\%)$ & Non-endometriosis, $\mathrm{n}=150(\%)$ & $p$-value \\
\hline Genotype & & $150(100)$ & NS \\
\hline Arg/Arg & $148(100)$ & 0 & \\
\hline Arg/Trp, Arg/Gln & 0 & 0 & \\
\hline Trp/Trp, Gln/Gln & 0 & $300(100)$ & NS \\
\hline Allele frequency & $296(100)$ & 0 & \\
\hline Arg & 0 & 0 & \\
\hline Trp & 0 & & \\
\hline Gln & &
\end{tabular}

NS: non-significantly different 
Table 5. Correlations of p53 codon 11, 72, and 248 gene polymorphisms with individual diseases

\begin{tabular}{|c|c|c|c|}
\hline \multicolumn{2}{|r|}{ Correlation } & \multicolumn{2}{|r|}{ Non-correlation } \\
\hline SNP Location & Diseases and references & SNP Location & Diseases and references \\
\hline Codon 11 & Gastric cancer [33] & Codon 72 & Gastric cancer [46] ${ }^{\mathrm{a}}$ \\
\hline Codon $72 *$ Arg & Gastric cancer [34] ${ }^{a}$ & Codon 72 & Cervical cancer $[47,48]^{\mathrm{b}}$ \\
\hline Codon $72 * A r g$ & Cutaneous melanoma [35] ${ }^{a}$ & Codon 72 & Cervical cancer and human papillomavirus-related diseases [49] $\mathrm{b}$ \\
\hline Codon $72 *$ Pro & Lung cancer $[36]^{\mathrm{a}}$ & Codon 72 & Colorectal cancer [38 ] ${ }^{a}$ \\
\hline Codon $72 * A r g$ & Lung cancer [37] ${ }^{\mathrm{b}}$ & Codon 72 & Endometriosis [31] ${ }^{a}$ \\
\hline Codon $72^{*}$ Arg & Breast cancer [38] ${ }^{a}$ & Codon 72 & Coronary artery disease $[50]^{a}$ \\
\hline codon 248 & Adrenal neoplasm [39] ${ }^{\mathrm{b}}$ & Codon 248 & Pancreatic cancer [13] ${ }^{\mathrm{b}}$ \\
\hline codon 248 & Squamous cell carcinoma in eyes [40] $]^{\mathrm{b}}$ & & \\
\hline codon 248 & Lung cancer $[41]^{\mathrm{b}}$ & & \\
\hline codon 248 & Ovarian cancer [42] ${ }^{\mathrm{b}}$ & & \\
\hline codon 248 & Gastric carcinoma [43] ${ }^{\mathrm{b}}$ & & \\
\hline codon 248 & Ulcerative colitis $[44]^{\mathrm{b}}$ & & \\
\hline codon 248 & Acute lymphoblastic leukemia [45] a & & \\
\hline
\end{tabular}

Figure 1. Electrophoresis of p53 codon 11, 72, and 248. (A) p53 codon 11 (Marker 1. Glu homozygote; 2. Gln/Lys heterozygote) (*products of non-complete PCR reaction with primers). (B) p53 codon 72 (Marker 1. Arg/Pro heterozygosity; 2. Arg homozygosity; 3. Pro homozygosity). (C) p53 codon 248 (marker 1. Trp/Gln heterozygosity; 2. Arg homozygosity)
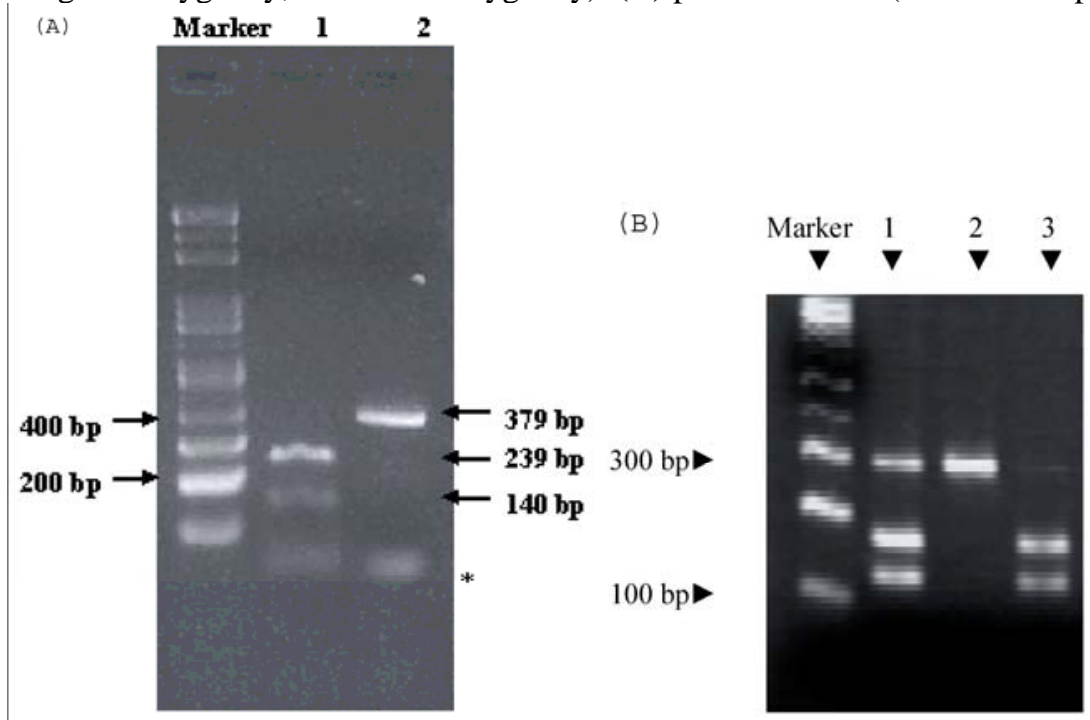

(C)

Marker 1

2

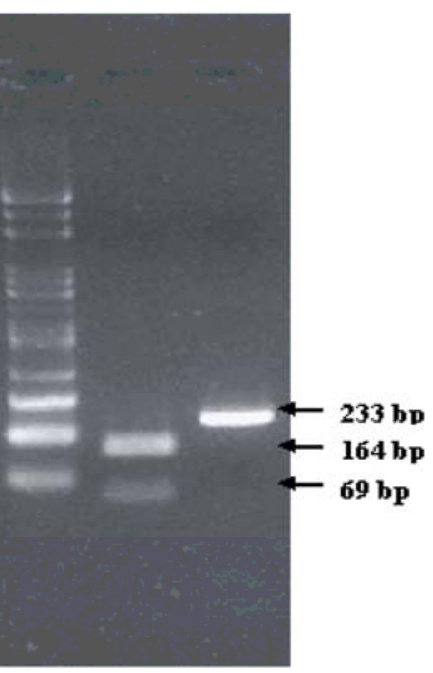

